\title{
Sterilization methods for humam teeth
}

\section{Métodos de esterilização de dentes humanos}

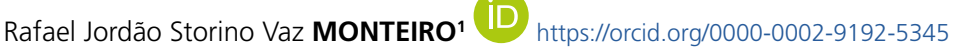 \\ Bárbara Daphini Matos SILVA ${ }^{2}$ iD https://orcid.org/0000-0002-5160-3237 \\ Lorena Esteves SILVEIRA2 ${ }^{2}$ https://orcid.org/0000-0002-3600-7103 \\ Maria Eugênia ALVAREZ-LEITE ${ }^{3}$ iD https://orcid.org/0000-0001-5065-8183 \\ Flavio Ricardo MANZI ${ }^{4}$ iD https://orcid.org/0000-0001-9467-5137
}

Claudia Valéria de Sousa Rezende PENIDO4 ${ }^{4}$ https://orcid.org/0000-0001-7567-282X

\begin{abstract}
Appropriate sterilization methods for dental substrate are necessary so that extracted teeth can be used in laboratory activities, since potentially pathogenic microorganisms may be present even if teeth have been cleaned. Objective: Evaluating the sterilization process of human teeth performed by microwave irradiation and autoclave sterilization. Methods: Fifty human premolar teeth were sectioned in two portions and distributed in two test groups: G1 - autoclave sterilization for 20 minutes, $1 \mathrm{Kgf} / \mathrm{cm}^{2}$, at $127^{\circ} \mathrm{C}$; G2 - Microwave irradiation in a recipient containing $100 \mathrm{ml}$ of distilled water, $900 \mathrm{~W}$ for 5 minutes.Before and after the decontamination process, all teeth were immersed in Brain Heart Infusion (BHI) broth to verify their contamination (positive control) and decontamination potential respectively. Results: The statistical analysis of the Friedman test $(p<0.05)$ showed that all the tested sterilization methods were statistically effective. Conclusion: These results show that both autoclaving and microwave irradiation are effective alternatives for the sterilization of human teeth.
\end{abstract}

Indexing terms: Deciduous tooth. Sterilization. Tooth.

\section{RESUMO}

Métodos de esterilização do substrato dental são necessários para que os dentes extraídos possam ser utilizados em atividades laboratoriais, pois microrganismos potencialmente patogênicos estão presentes mesmo em dentes que foram limpos. Objetivo: Avaliar o processo de esterilização de dentes humanos em autoclave e microondas. Métodos: Cinquenta dentes pré-molares humanos foram seccionados em duas porções e distribuídos em dois grupos de teste: G1 - esterilização em autoclave por 20 minutos, $1 \mathrm{Kgf} / \mathrm{cm}^{2}$, a $127^{\circ} \mathrm{C}$; G2 - Irradiação por microondas em um recipiente contendo 100ml de água destilada, 900W por 5 minutos. Antes e após o processo de descontaminação, todos os dentes foram imersos em caldo Brain Heart Infusion (BHI) para verificar sua contaminação

\footnotetext{
$\checkmark v \nabla$
}

1 Universidade Federal de Minas Gerais, Faculdade de Odontologia, Departamento de Periodontia. Av. Antônio Carlos, 6627, Pampulha, 31270-901, Belo Horizonte, MG, Brasil. Correspondence to: RJSV MONTEIRO. E-mail: <rafaelstorino@hotmail.com>.

2 Pontifícia Universidade Católica de Minas Gerais, Faculdade de Odontologia. Belo Horizonte, MG, Brasil.

3 Pontifícia Universidade Católica de Minas Gerais, Faculdade de Odontologia, Departamento de Microbiologia. Belo Horizonte, MG, Brasil.

${ }^{4}$ Pontifícia Universidade Católica de Minas Gerais, Faculdade de Odontologia, Departamento de Radiologia. Belo Horizonte, MG, Brasil.

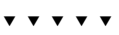

How to cite this article

Monteiro RJSV, Silva BDM, Silveira LE, Alvarez-Leite ME, Manzi FR, Penido CVSR. Sterilization methods for humam teeth. RGO, Rev Gaúch Odontol. 2020;68: e20200035b. http://dx.doi.org/10.1590/1981-863720200003520190072 
(controle positivo) e potencial de descontaminação, respectivamente. Resultados: A análise estatística do teste de Friedman (p <0,05) mostrou que todos os métodos de esterilização testados foram estatisticamente eficazes. Conclusão: Esses resultados mostram que tanto a autoclave quanto a irradiação por microondas são alternativas eficazes para a esterilização de dentes humanos.

Termos de indexação: Dente. Esterilização. Micro-Ondas.

\section{INTRODUCTION}

In Dentistry, students and researchers need human or animal teeth to study the dental anatomy and histology, as well as to perform pre-clinical training and conducting scientific researches. In Brazil, Law 9.434 considers human teeth as organs, therefore, its origin must be known. Like any organ in the human body, teeth are a potential source of pathogenic microorganisms and require sterilization for cross-infection control. The use of extracted teeth has motivated researchers to question the effectiveness of the sterilization methods and the possible damages caused to samples due to the method applied [1]. Extracted or exfoliated teeth contain residues of saliva and blood fluids that may have several pathogen agents. Therefore, when teeth are used without proper sterilization methods, they become a potential source of infection and contamination for researchers, students, and volunteers considering in situ experiments. To control cross-contamination, appropriate sterilization methods should be applied prior to using teeth for scientific purposes. It is necessary that the disinfection or sterilization method applied to the extracted teeth does not change the properties of the dental substrate, so that it does not constitute a variable that interferes with the research [2].

Many methods report on the disinfection or sterilizing methods of teeth, showing that some chemicals used to disinfectcan damage the dental structure, such as iodoform, sodium hypochlorite, 10\% formalin, glutaraldehyde, PVPI, 70\% alcohol, vinegar [3]. Additionally, for the decontamination process to be effective, some substances demand several days for the disinfection or sterilization process to be completed.Autoclaving is the most effective sterilization method since it is lethal to all microbiological life. To carry out the sterilization process without damaging the organic dental structure, the temperature should reach around $121^{\circ} \mathrm{C}$, however it may change the enamel and dentin composition. This method is considered the 'gold standard' as it provides the best results in researches. Currently, another disinfection method that has been discussed is microwave irradiation, which heats materials composed of water molecules and several other components, causing the molecules vibration, generating heat. This thermal energy accelerates the ions, leading to the proteins' denaturation comprising the microorganisms. It is unknown if this energy has established all the decontamination effects originated by the microwave [1]. Microwave disinfection is indicated for several purposes such as disinfection of laboratory microbiological materials, underwear infected with C. albicans, dental prostheses and instruments used in medicine and dentistry [5]. This research study aimed at performing an in vitro evaluation, applying the microbiological culture method, of the decontamination of permanent teeth using autoclave and microwave as sterilization/decontamination methods.

\section{METHODS}

The present study was approved by the Research Ethics Committee of the Pontifical Catholic University of Minas Gerais (CAE: 27754614.8.0000.5137). In this study, all teeth were donated by patients who were treated at the undergraduate and postgraduate clinic of the Pontifical Catholic University of Minas Gerais (PUC Minas), after filling out the standard donation term of the Human Teeth Bank of the Pontifical Catholic University of Minas Gerais (appendix 1). Fifty healthy human premolars were selected for this study after a thorough visual inspection. The teeth were sectioned longitudinally into two equal parts, using a straight-piece carborundum disk, under indirect irrigation with distilled water to prevent overheating. To create a control group and verify that the teeth had bacterial load prior to the decontamination process, the two halves of each specimen were immersed in a test tube containing $8 \mathrm{ml}$ of Brain Heart Infusion broth (Acmedia Manufacturers, Inc. Baltimore, Mayland), using sterile forceps in a laminar flow hood (Veco-Campinas, São Paulo - Brazil). Subsequently, they were stirred, for one minute, in the Vortex system (Biomatic - Porto Alegre, Rio Grande do Sul - Brazil) and, then, removed, thereby creating 50-control culture media. These 50-control culture media were incubated under aerobic conditions in a bacteriological oven at $37^{\circ}$ Celsius. Thereafter, each half of a single tooth was divided into two groups: G1 - autoclave sterilization (Sercon model AHMC5 
- Mogi das Cruzes, São Paulo, Brazil), in a recipient containing $100 \mathrm{ml}$ of distilled water, wrapped in surgical grade paper, for 15 minutes, at $1700 \mathrm{~W}, 127^{\circ} \mathrm{C}$, without undergoing the drying cycle (positive control) 7; G2 - microwave sterilization (Consul model CMY34ARHNA - Manaus, Amazonas - Brazil), in a recipient containing $100 \mathrm{ml}$ of distilled water, also wrapped in surgical grade paper, at 900W, for 3 minutes. The choice of $900 \mathrm{~W}$ was based on studies showing that this voltage produces effective disinfection $[1,6]$.

Sequentially, post-decontamination specimens ( $G 1$ and G2) were also processed in a laminar flow hood, immersed in tubes containing $8 \mathrm{~mL}$ of Brain Heart Infusion broth, and stirred in the Vortex system for 1 minute. Then, they were transferred to another tube containing $\mathrm{BHI}$ broth as well. This procedure intended to create two culture media, with microorganisms from the same specimen, so that one of them (subgroup A) could be incubated in bacteriological oven at $37^{\circ} \mathrm{C}$, for 72 hours, under aerobic conditions, and the other (subgroup B) could, also, be incubated in bacteriological oven, during the same time and temperature, but under microaerophilic conditions.

The data resulting from the microbiological tests from each sterilization process, under aerobic and microaerophilic conditions, were statistically analyzed (Friedman's test) with a significance level of $5 \%$.

\section{RESULTS}

The media readingwas performed 72 hours after the procedure and the results indicated that, among the 50-control culture media, all the ones that were not submitted to any sterilization and/or decontamination process presented medium turbidity, indicating contamination.

None of the 50 specimens from $\mathrm{G} 1$ which were submitted to the autoclave cycle showed contamination under the tested conditions. As for the $\mathrm{G} 2$ specimens submitted to microwave decontamination, a small number showed medium turbidity, indicating that there was contamination yet, as shown in figure 1 .

For the statistical analysis, the Friedman test ( $p$ $<0.05$ ) was applied and all the tested decontamination methods were statistically effective, with a statistically significant difference for the control group. Even though the autoclave did not show any contaminated sample and the microwave had few, there was no statistical difference between them.

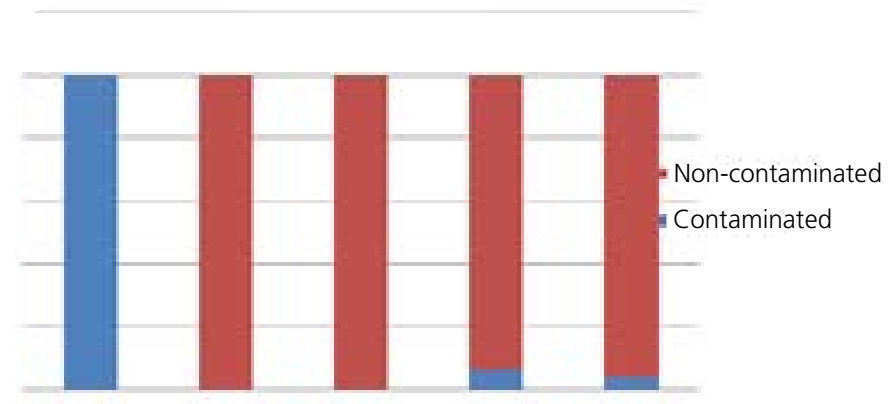

Figure 1. Comparison from the decontamination potential of the tested methods.

Note: ${ }^{*}$ Control Group - Statistically significant difference when compared to all the decontamination methods tested by the Friedman statistical test $(p<0.05)$.

\section{DISCUSSION}

The possibility of occurring contamination from the use of extracted human teeth leads to the importance of having sterilization processes so that there is always cross-infection control. Therefore, there is a continuous search for sterilization processes that are practical and low cost. As also shown in this research study, in which all specimens were free from contamination under the tested conditions, the autoclave is the gold standard method for sterilization processes. However, it is a device that requires long working hours, operational knowledge and constant vigilance [1].Microwave ovens would be an option for new devices that have been studied currently. This sterilization method works by converting electrical energy into the microwave electromagnetic field, or electromagnetic waves, which are produced by the magnetron, which generates valve capable of producing microwave beams that are transferred to the oven cavity. These waves can be absorbed, transmitted or reflected by the material on which they are incident. Once absorbed, they interact with the material molecules, generating heat in their interior, promoting heating and generating the sterilizing effect. This would explain the result achieved on the research, since both groups tested in microwave, both aerobic and microaerophilic, were statistically possible alternatives $[1,5,6]$.

Studies suggest that there are no thermal effects generated by the action of microwave devices, which are directly resulting from the interaction of the electromagnetic field with the molecules. These would promote changes in the intracellular molecules, causing modifications in the cellular morphology and its eventual disintegration. Since the cell has high water content, this fact would explain the sensitivity of microorganisms to irradiation by microwave. Thus, the microwave would 
be absorbed by important biological molecules, causing structural changes in the most peripheral layer around the biological macromolecules, changing their stability and leading to denaturation [7-9].

In this research study, the microwave oven with a power of $900 \mathrm{~W}$ was used for 5 minutes. The choice was based on studies which demonstrated that, in similar power and time, disinfection was produced. The teeth were immersed in water to prevent them from dehydrating during the cycle, and because prior studies showed that the disinfection effect of microwaves on microorganisms only occurs in the presence of water, indicating that the liquid is essential for absorption of microwave energy $[1,5,6]$.

Sterilization is the process by which all microorganisms, including viruses, bacteria, fungi and spores are destroyed. Disinfection is the destruction of most, but, not necessarily, all the microorganisms, since the highly resistant ones remain viable [10]. In the present study, although there was no statistically difference between the experimental groups, it is not properto state that the microwave sterilization method can be recommended as the only viable method. As some samples remain contaminated, further testing is required so that no extracted tooth manipulator is exposed to biological hazards. Tests with other exposure time to the microwave, or even with modifications in the preparation thereof prior to the sterilization cycle, may eventually show the feasibility of this alternative method.

\section{CONCLUSION}

These results show that the use of autoclave and microwave are effective sterilization and disinfection methods. From the results achieved in this preliminary investigation, microwave irradiation can be a possible alternative to disinfect human teeth, as it is an efficient, fast and less expensive procedure not using radiation.

\section{Acknowledgments}

This research study was carried out with the financial support from the Foundation for Research Support (FAPEMIG) under the PROBIC project - PUC MINAS.

\section{Collaborators}

RJSV MONTEIRO and CVSR PENIDO, conception and design, analysis and interpretation of data, review and approval of the final version of the article. BDM SILVA and LE SILVEIRA, conception and design. ME ALVAREZ-LEITE, conception and design, analysis and interpretation of data, review and approval of the final version of the article. FR MANZI, statistical analysis and interpretation of results.

\section{REFERENCES}

1. Monteiro RJSV, Silva BDM, Silveira LE, Alvarez-Leite ME, Manzi FR, Penido CVSR. Microwave and autoclave usage in human teeth sterilization. RGO, Rev Gaúch Odontol. 2018;66(4):317-320. http://dx.doi.org/10.1590/1981-86372 0180004000043437

2. Michaud PL, Maleki M, Mello I. Effect of different disinfection/ sterilization methods on risk of fracture of teeth used in preclinical dental education. J Dent Educ. 2018;82(1):84-87. http://dx.doi.org/10.21815/JDE.018.012

3. Sancakli HS, Siso SH, Yildiz SO, Gökçe YB. antibacterial effect of surface pretreatment techniques against streptococcus mutans. Niger J Clin Pract. 2018 Feb;21(2):170-175. http:// dx.doi.org/10.4103/njcp.njcp_98_16

4. Tijare M, Smitha D, Kasetty S, Kallianpur S, Gupta S, Amith H. Vinegar as a disinfectant of extracted human teeth for dental educational use. J Oral MaxillofacPathol. 2014;18(1):14-8. http://dx.doi.org/10.4103/0973-029X.131883

5. Vasconcelos LR, Consani RL, Mesquita MF, Sinhoreti MA. Effect of chemical and microwave disinfection on the surface microhardness of acrylic resin denture teeth. J Prosthodont. 2013;22(4):298-303. http://dx.doi.org/10.1111/jopr.12009

6. Viana PS, Machado AL, Giampaolo ET, Pavarina AC, VerganiCE. Disinfection of bovine enamel by microwave irradiation: effect on the surface microhardness and demineralization/ remineralization processes. Caries Res. 2010;44(4):349-57. https://doi.org/10.1159/000318528

7. Seo SH, Han I, Lee HS, Choi JJ, Choi EH, Kim KN, et al. Antibacterial activity and effect on gingival cells of microwavepulsed non-thermal atmospheric pressure plasma in artificial saliva. Sci Rep. 2017;7(1):8395. http://dx.doi.org/10.1038/ s41598-017-08725-0

8. Zhu W, Cui Y, Feng X, Li Y, Zhang W, Xu J, et al. The apoptotic effect and the plausible mechanism of microwave radiation on rat myocardial cells. Can J Physiol Pharmacol. 2016;94(8):849-57. http://dx.doi.org/10.1139/cjpp-2015-0537

9. Asano M, Sakaguchi M, Tanaka S, Kashimura K, Mitani $T$, Kawase M,et al. Effects of Normothermic Conditioned Microwave Irradiation on Cultured Cells Using an Irradiation System with Semiconductor Oscillator and Thermo-regulatory Applicator. Sci Rep. 2017;7:41244. http://dx.doi.org/10.1038/ srep41244

10. Drosnock MA. The Latest Developments in AAMI's Sterilization Standards. Biomed Instrum Technol. 2019;53(s2):6-8. http:// dx.doi.org/10.2345/0899-8205-53.s2.6

Received on: 28/4/2019

Final version resubmitted on: 11/6/2019 Approved on: 18/6/2020 